\title{
The effects of progesterone on the alpha2-adrenergic receptor subtypes in late-pregnant uterine contractions in vitro
}

\author{
Judit Hajagos-Tóth', Judit Bóta', Eszter Ducza', Reza Samavati², Anna Borsodi², Sándor Benyhe² \\ and Róbert Gáspár ${ }^{1 *}$
}

\begin{abstract}
Background: The adrenergic system and progesterone play major roles in the control of the uterine function. Our aims were to clarify the changes in function and expression of the $a_{2}$-adrenergic receptor (AR) subtypes after progesterone pretreatment in late pregnancy.

Methods: Sprague Dawley rats from pregnancy day 15 were treated with progesterone for 7 days. The myometrial expressions of the $a_{2}$-AR subtypes were determined by RT-PCR and Western blot analysis. In vitro contractions were stimulated with (-)-noradrenaline, and its effect was modified with the selective antagonists BRL $44408\left(a_{2 A}\right), A R C$ $239\left(\mathrm{a}_{2 \mathrm{~B} / \mathrm{C}}\right)$ and spiroxatrine $\left(\mathrm{a}_{2 \mathrm{~A}}\right)$. The accumulation of myometrial cAMP was also measured. The activated G-protein level was investigated via GTPYS binding assays.

Results: Progesterone pretreatment decreased the contractile effect of (-)-noradrenaline through the $\mathrm{a}_{2}$-ARs. The most significant reduction was found through the $a_{2 B}$-ARs. The mRNA of all of the $a_{2}$-AR subtypes was increased. Progesterone pretreatment increased the myometrial CAMP level in the presence of BRL $44408(p<0.001)$, spiroxatrine $(p<0.001)$ or the spiroxatrine + BRL 44408 combination $(p<0.05)$. Progesterone pretreatment increased the G-protein-activating effect of (-)-noradrenaline in the presence of the spiroxatrine + BRL 44408 combination.

Conclusions: The expression of the $a_{2}$-AR subtypes is progesterone-sensitive. It decreases the contractile response of (-)-noradrenaline through the $a_{2 B}-A R$ subtype, blocks the function of $a_{2 A}-A R$ subtype and alters the $G$ protein coupling of these receptors, promoting a $\mathrm{G}_{\mathrm{s}}$-dependent pathway. A combination of $\mathrm{a}_{2 \mathrm{C}}-\mathrm{AR}$ agonists and $\mathrm{a}_{2 \mathrm{~B}}-\mathrm{AR}$ antagonists with progesterone could be considered for the treatment or prevention of preterm birth.
\end{abstract}

Keywords: Progesterone, Gestation, Rat, Myometrium, $a_{2}$-adrenergic receptor subtypes

\section{Background}

The physiology of uterine quiescence and contractility is very complex. Myometrial contraction is regulated by a number of factors, such as female sexual hormones, the adrenergic receptor (AR) system, ion channels and transmitters. However, the exact cellular and molecular events are still in question. Dysregulation of the myometrial contractility can lead to either preterm or slow-toprogress labor. It is therefore crucial to understand the mechanisms that regulate uterine contractility in order

\footnotetext{
* Correspondence: gaspar@pharm.u-szeged.hu

'Department of Pharmacodynamics and Biopharmacy, Faculty of Pharmacy,

University of Szeged, Szeged H-6701, P.O. Box 121, Hungary

Full list of author information is available at the end of the article
}

to prevent or treat the pathological processes related to the pregnant myometrium [1-4].

It is well known that the female sexual hormone progesterone is responsible for uterine quiescence [5, 6], while estrogens have major role in myometrial contractions $[1,7]$. The progesterone level normally declines at term prior to the development of labor and it is therefore used to prevent threatening preterm birth $[8,9]$. Progesterone and estrogen also play an important role in the regulation of the adrenergic system [10]. Estrogen decreases the expressions of the $\alpha_{2}$-AR subtypes and alters the myometrial contracting effect of (-)-noradrenaline by reduced coupling of the $\alpha_{2 \mathrm{~B}}$-ARs to $G_{i}$ protein [11]. Progesterone enhances the synthesis of $\beta_{2}$-ARs 
during gestation [12-14], and the number of activated G-proteins [12, 15], and $\beta_{2}$-AR agonists can therefore theoretically be combined with progesterone in threatening premature labour [16]. The myometrial $\alpha_{1}-\mathrm{AR}$ is also influenced by progesterone. It induces a change in the $\mathrm{G}_{\mathrm{q}} / \mathrm{G}_{\mathrm{i}}$-activating property of the $\alpha_{1 \mathrm{AD}}-\mathrm{AR}$ in rats [17]. However, the effect of progesterone on the myometrial $\alpha_{2}$-AR subtypes is still unknown. Since progesterone has a major role in myometrial quiescence during human parturition [18], it seems important to know its direct influence on the $\alpha_{2}$-AR subtypes, which are also involved in the mechanism of uterine contractions [19].

The $\alpha_{2}$-ARs have been divided into three groups [20, $21]$, the $\alpha_{2 \mathrm{~A}}, \alpha_{2 \mathrm{~B}}$ and $\alpha_{2 C}$ subtypes. All of three receptor subtypes bind to the pertussis toxin-sensitive $G_{i}$ protein [22] and decreases the activity of adenylyl cyclase (AC) [23], but under certain circumstances $\alpha_{2}$-ARs can also couple to $G_{s}$-proteins and increase adenylyl cyclase activity [24]. All three receptor subtypes are involved in various physiological functions, and especially in the cardiovascular and central nervous systems [25]. Furthermore, all of them have been identified in both the pregnant and the non-pregnant myometrium, and have been shown to take part in both increased and decreased myometrial contractions [26]. The $\alpha_{2 \mathrm{~B}}$-ARs predominate and mediate contraction at the end of gestation in rats, decreasing the intracellular cAMP level, while the stimulation of the myometrial $\alpha_{2 \mathrm{~A}^{-}}$and $\alpha_{2 \mathrm{C}}$-ARs increases the cAMP level, and mediates only weak contractions [27].

Since no data are available on the effects of progesterone on the myometrial functions of the different $\alpha_{2}$-AR subtypes, we set out to clarify the changes in expression and function of the $\alpha_{2 A^{-}}, \alpha_{2 B^{-}}$and $\alpha_{2 C^{-}}$AR subtypes after progesterone pretreatment on the last day of pregnancy in rats.

\section{Methods}

The animal experimentation was carried out with the approval of the Hungarian Ethical Committee for Animal Research (permission number: IV/198/2013). The animals were treated in accordance with the EU Directive 2010/63/EU for animal experiments and the Hungarian Act for the Protection of Animals in Research (XXVIII. tv. 32.\$).

\section{Housing and handling of the animals}

Sprague-Dawley rats were obtained from the INNOVO Ltd. (Gödöllö, Hungary) and were housed under controlled temperature $\left(20-23{ }^{\circ} \mathrm{C}\right)$, in humidity $(40-60 \%)$ and light (12 h light/dark regime)-regulated rooms. The animals were kept on a standard rodent pellet diet (INNOVO Ltd., Isaszeg, Hungary), with tap water available ad libitum.

\section{Mating of the animals}

Mature female (180-200 g) and male (240-260 g) Sprague-Dawley rats were mated in a special mating cage in the early morning hours. A time-controlled metal door separated the rooms for the male and female animals. The separating door was opened before dawn (4 a.m.) Within $4-5 \mathrm{~h}$ after the possibility of mating, intercourse was confirmed by the presence of a copulation plug or vaginal smears. In positive cases, the female rats were separated and this was regarded as the first day of pregnancy.

\section{In vivo sexual hormone treatments of the rats}

The progesterone (Sigma-Aldrich, Budapest, Hungary) pretreatment of the pregnant animals was started on day 15 of pregnancy. Progesterone was dissolved in olive oil and injected subcutaneously every day up to day 21 in a dose of $0.5 \mathrm{mg} / 0.1 \mathrm{ml}$ [28].

On day 22, the uterine samples were collected, and contractility and molecular pharmacological studies were carried out.

\section{RT-PCR studies}

Tissue isolation: Rats (250-350 g) were sacrificed by $\mathrm{CO}_{2}$ asphyxiation. Fetuses were sacrificed by immediate cervical dislocation. The uterine tissues from pregnant animals (tissue between two implantation sites) were rapidly removed and placed in RNAlater Solution (Sigma-Aldrich, Budapest, Hungary). The tissues were frozen in liquid nitrogen and then stored at $-70{ }^{\circ} \mathrm{C}$ until the extraction of total RNA.

Total RNA preparation from tissue: Total cellular RNA was isolated by extraction with guanidinium thiocyanate-acid-phenol-chloroform according to the procedure of Chomczynski and Sacchi [29]. After precipitation with isopropanol, the RNA was washed with $75 \%$ ethanol and then re-suspended in diethyl pyrocarbonate-treated water. RNA purity was controlled at an optical density of $260 / 280 \mathrm{~nm}$ with BioSpec Nano (Shimadzu, Japan); all samples exhibited an absorbance ratio in the range 1.6-2.0. RNA quality and integrity were assessed by agarose gel electrophoresis.

Reverse transcription and amplification of the PCR products was performed by using the TaqMan RNA-toCTTM 1-Step Kit (Life Technologies, Budapest, Hungary) and the ABI StepOne Real-Time cycler. RT-PCR amplifications were performed as follows: $48{ }^{\circ} \mathrm{C}$ for $15 \mathrm{~min}$ and $95{ }^{\circ} \mathrm{C}$ for $10 \mathrm{~min}$, followed by 40 cycles at $95{ }^{\circ} \mathrm{C}$ for $15 \mathrm{~s}$ and $60{ }^{\circ} \mathrm{C}$ for $1 \mathrm{~min}$. The generation of specific PCR products was confirmed by melting curve analysis. Table 1 contains the assay IDs for the used primers. The amplification of $\beta$-actin served as an internal control. All samples were run in triplicates. The fluorescence intensities of the probes were plotted against PCR cycle numbers. The 
Table 1 Parameters of the applied primers and PCR reactions. The real-time reverse transcription polymerase chain reactions were used to determine the changes in the mRNA expression. In our studies the parameters of inventoried TaqMan assays were defined by Life Technologies (ThermoFisher Scientific, Hungary)

\begin{tabular}{lllllll}
\hline TaqMan assays & Assay ID (Life Technologies, Hungary) & Accession number & Assay location & Amplicon length & Annealing temp. $\left({ }^{\circ} \mathrm{C}\right)$ & Reaction volume $(\mu$ ) \\
\hline $\mathrm{a}_{2 \mathrm{~A}}$-AR & Rn00562488_s1 & NM_012739.3 & 1350 & 72 & 60 & 20 \\
$\mathrm{a}_{2 \mathrm{~B}}$-AR & Rn00593312_s1 & NM_138505.2 & 1451 & 63 & 60 & 20 \\
$\mathrm{a}_{2 \mathrm{C}}$-AR & Rn00593341_s1 & NM_138506.1 & 653 & 111 & 60 & 20 \\
$\beta$-actin & Rn00667869_m1 & NM_031144.3 & 881 & 91 & 60 & 20 \\
\hline
\end{tabular}

amplification cycle displaying the first significant increase in the fluorescence signal was defined as the threshold cycle $(\mathrm{CT})$.

\section{Western blot analysis}

Twenty $\mu \mathrm{g}$ of protein per well was subjected to electrophoresis on 4-12\% NuPAGE Bis-Tris Gel in XCell SureLock Mini-Cell Units (Life Technologies, Budapest, Hungary). Proteins were transferred from gels to nitrocellulose membranes, using the iBlot Gel Transfer System (Life Technologies, Hungary). The antibody binding was detected with the WesternBreeze Chromogenic Western blot immundetection kit (Life Technologies, Budapest, Hungary). The blots were incubated on a shaker with $\alpha_{2 \mathrm{~A}}-\mathrm{AR}, \alpha_{2 \mathrm{~B}}-\mathrm{AR}, \alpha_{2 \mathrm{C}}-\mathrm{AR}$ and $\beta$-actin polyclonal antibody (Santa Cruz Biotechnology, California, 1:200) in the blocking buffer. Images were captured with the EDAS290 imaging system (Csertex Ltd., Hungary), and the optical density of each immunoreactive band was determined with Kodak 1D Images analysis software. Optical densities were calculated as arbitrary units after local area background subtraction.

\section{Isolated organ studies}

Uteri were removed from the 22-day-pregnant rats (250-350 g). $5 \mathrm{~mm}$-long muscle rings were sliced from both horns of the uterus and mounted vertically in an organ bath containing $10 \mathrm{ml}$ de Jongh solution (composition: $137 \mathrm{mM} \mathrm{NaCl}, 3 \mathrm{mM} \mathrm{KCl}, 1 \mathrm{mM} \mathrm{CaCl}_{2}, 1 \mathrm{mM}$ $\mathrm{MgCl}_{2}, 12 \mathrm{mM} \mathrm{NaHCO}, 4 \mathrm{mM} \mathrm{NaH} \mathrm{PO}_{4}, 6 \mathrm{mM}$ glucose, $\mathrm{pH}=7.4)$. The temperature of the organ bath was maintained at $37{ }^{\circ} \mathrm{C}$, and carbogen $\left(95 \% \mathrm{O}_{2}+5 \% \mathrm{CO}_{2}\right)$ was perfused through the bath. After mounting, the rings were allowed to equilibrate for approximately 60 min before experiments were started, with a buffer change every $15 \mathrm{~min}$. The initial tension of the preparation was set to about $1.5 \mathrm{~g}$ and the tension dropped to about $0.5 \mathrm{~g}$ by the end of the equilibration period. The tension of the myometrial rings was measured with a gauge transducer (SG-02; Experimetria Ltd., Budapest, Hungary) and recorded with a SPEL Advanced ISOSYS Data Acquisition System (Experimetria Ltd., Budapest, Hungary). In the following step contractions were elicited with $(-)$-noradrenaline $\left(10^{-8}\right.$ to $\left.10^{-4.5} \mathrm{M}\right)$ and cumulative concentration-response curves were constructed in each experiment in the presence of doxazosin $\left(10^{-7} \mathrm{M}\right)$ and propranolol $\left(10^{-5} \mathrm{M}\right)$ in order to avoid $\alpha_{1^{-}}$ adrenergic and $\beta$-adrenergic actions. Selective $\alpha_{2}$-AR subtype antagonists (each $10^{-7} \mathrm{M}$ ), propranolol and doxazosin were left to incubate for $20 \mathrm{~min}$ before the administration of contracting agents. Following the addition of each concentration of (-)-noradrenaline, recording was performed for $300 \mathrm{~s}$. Concentration-response curves were fitted and areas under curves (AUC) were evaluated and analysed statistically with the Prism 4.0 (Graphpad Software Inc. San Diego, CA, USA) computer program. From the AUC values, $\mathrm{E}_{\max }$ and $\mathrm{EC}_{50}$ values were calculated. Statistical evaluations were carried out with the ANOVA Dunnett test or the two-tailed unpaired t-test.

\section{Measurement of uterine CAMP accumulation}

Uterine cAMP accumulation was measured with a commercial cAMP Enzyme Immunoassay Kit (Cayman Chemical, USA). Uterine tissue samples (control and $17 \beta$-estradiol-treated) from 22 -day-pregnant rats were incubated in an organ bath $(10 \mathrm{ml})$ containing de Jongh solution $\left(37{ }^{\circ} \mathrm{C}\right.$, perfused with carbogen). Isobutylmethylxanthine $\left(10^{-3} \mathrm{M}\right)$, doxazosin $\left(10^{-7} \mathrm{M}\right)$, propranolol $\left(10^{-5} \mathrm{M}\right)$ and the investigated subtype-selective $\alpha_{2}$-AR antagonists (each $10^{-7} \mathrm{M}$ ) were incubated with the tissues for $20 \mathrm{~min}$, and $(-)$-noradrenaline $\left(3 \times 10^{-6} \mathrm{M}\right)$ were added to the bath for $10 \mathrm{~min}$. At the end of the (-)-noradrenaline incubation period, forskolin $\left(10^{-5} \mathrm{M}\right)$ was added for another $10 \mathrm{~min}$. After stimulation, the samples were immediately frozen in liquid nitrogen and stored until the extraction of cAMP [30]. Frozen tissue samples were then ground, weighed, homogenized in 10 volumes of ice-cold 5\% trichloroacetic acid and centrifuged at $1000 \mathrm{~g}$ for $10 \mathrm{~min}$. The supernatants were extracted with 3 volumes of water-saturated diethyl ether. After drying, the extracts were stored at $-70{ }^{\circ} \mathrm{C}$ until the cAMP assay. Uterine cAMP accumulation was measured with a commercial competitive cAMP EIA Kit; tissue cAMP levels were expressed in $\mathrm{pmol} / \mathrm{mg}$ tissue.

\section{$\left[{ }^{35} \mathrm{~S}\right] \mathrm{GTP}$ S $\mathrm{S}$ binding assay}

Uteri were removed and homogenized in 20 volumes (w/v) of ice-cold buffer (10 mM Tris-HCl, 1 mM EDTA, 
$0.6 \mathrm{mM} \mathrm{MgCl} 2$, and $0.25 \mathrm{M}$ sucrose, $\mathrm{pH} 7.4$ ) with an Ultra Turret T25 (Janke \& Kunkel, Staufen, Germany) homogenizer, and the suspension was then filtered on four layers of gauze and centrifuged $\left(40,000 \mathrm{~g}, 4{ }^{\circ} \mathrm{C}, 20\right.$ min). After centrifugation, the pellet was resuspended in a 5 -fold volume of buffer. The protein contents of the samples were diluted to $10 \mathrm{mg}$ protein/sample. Membrane fractions was incubated in a final volume of $1 \mathrm{ml}$ at $30{ }^{\circ} \mathrm{C}$ for $60 \mathrm{~min}$ in Tris-EGTA buffer ( $\mathrm{pH} \mathrm{7.4)} \mathrm{com-}$ posed of $50 \mathrm{mM}$ Tris- $\mathrm{HCl}, 1 \mathrm{mM}$ EGTA, $3 \mathrm{mM} \mathrm{MgCl}$, $100 \mathrm{mM} \mathrm{NaCl}$, containing $20 \mathrm{MBq} / 0.05 \mathrm{~cm}^{3}\left[{ }^{35} \mathrm{~S}\right] \mathrm{GTP} \gamma \mathrm{S}$ (0.05 nM) (Sigma Aldrich, Budapest, Hungary), together with increasing concentrations $\left(10^{-9}-10^{-5} \mathrm{M}\right)$ of (-)-noradrenaline. BRL 44408, ARC 239 and spiroxatrine were used in a fixed concentration of $0.1 \mu \mathrm{M}$. For the blocking of $\alpha_{1}$ - and $\beta$-ARs, doxazosin and propranolol were used in a fixed concentration of $10 \mu \mathrm{M}$. Total binding was measured in the absence of the ligands, non-specific binding was determined in the presence of $10 \mu \mathrm{M}$ unlabeled GTP $\gamma \mathrm{S}$ and subtracted from total binding. The difference represents basal activity. Bound and free $\left[{ }^{35} \mathrm{~S}\right] \mathrm{GTP} \gamma \mathrm{S}$ were separated by vacuum filtration through Whatman GF/B filters with Brandel M24R Cell harvester. Filters were washed three times with $5 \mathrm{ml}$ ice-cold buffer ( $\mathrm{pH} 7.4$ ), and the radioactivity of the dried filters was detected in UltimaGold ${ }^{\mathrm{m}} \mathrm{MV}$ scintillation cocktail with Packard Tricarb 2300TR liquid scintillation counter [31]. The $\left[{ }^{35} \mathrm{~S}\right] \mathrm{GTP} \gamma \mathrm{S}$ binding experiments were performed in triplicate and repeated at least three times.

$G_{i}$ protein was inhibited with pertussis toxin (Sigma Aldrich, Budapest, Hungary) in a concentration of $500 \mathrm{ng} / \mathrm{ml}$ after the addition of protein and GDP to the Tris-EGTA buffer $30 \mathrm{~min}$ before $\left[{ }^{35} \mathrm{~S}\right] \mathrm{GTP} \gamma \mathrm{S}$.

\section{Results}

\section{RT-PCR and Western blot studies}

The mRNA expression of each $\alpha_{2}$-AR subtype (Fig. 1a-c) was significantly increased after progesterone pretreatment as compared with the non-treated uteri $(p<0.05)$. The results of Western blot analysis at the level of protein expression revealed a significant increase in each $\alpha_{2}$-AR subtype, which correlated with the PCR results (Fig. 2a-f).

\section{Isolated organ studies}

In the 22-day-pregnant myometrium, (-)-noradrenaline in the concentration range of $10^{-8}$ to $10^{-4.5} \mathrm{M}$ increased the myometrial contractions $\left(\mathrm{E}_{\max }=274.1 \pm 47.1\right)$ (Fig. 3a). After progesterone pretreatment, the myometrial contracting effect of (-)-noradrenaline was decreased $\left(E_{\max }=\right.$ $94.0 \pm 14.4 ; p<0.01$ ) (Fig. 3b). The $\mathrm{EC}_{50}$ and $\mathrm{E}_{\max }$ values of the curves are listed in Table $2 \mathrm{a}$.

In the presence of the $\alpha_{2 \mathrm{~A}}-\mathrm{AR}$ antagonist BRL 44408, progesterone pretreatment decreased the (-)-noradrenaline-

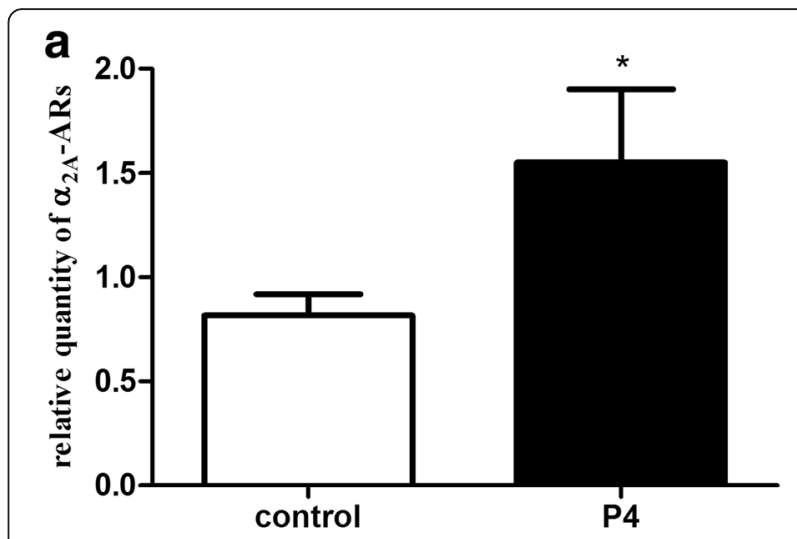

b
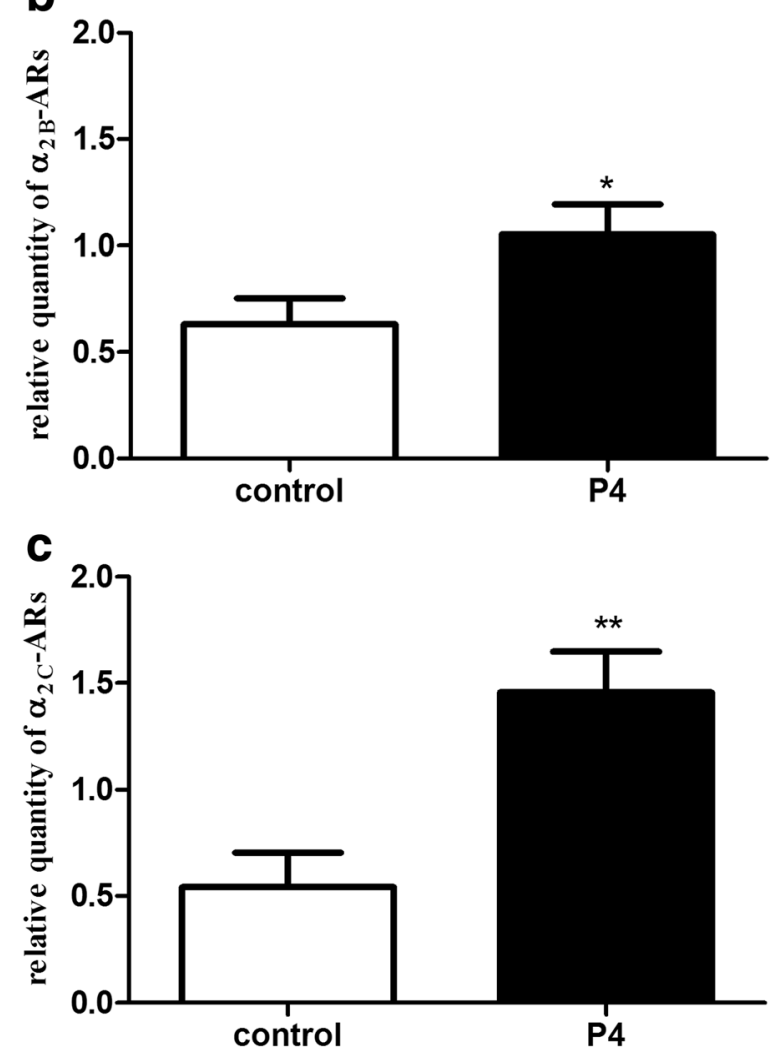

Fig. 1 Changes in the myometrial $m R N A$ and protein expression of

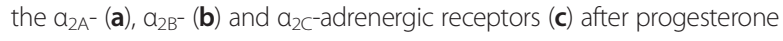
pretreatment. The statistical analyses were carried out with the two-tailed unpaired t-test. ${ }^{*} p<0.05 ;{ }^{* *} p<0.01$

evoked contractions as compared with the progesteronetreated control $(p<0.05)$ (Fig. 3b). BRL 44408 enhanced the (-)-noradrenaline-induced contractions, this being markedly reduced by progesterone pretreatment $(p<0.001)$ (Fig. 3a, b; Table 2b).

In the presence of the $\alpha_{2 \mathrm{~B} / \mathrm{C}}-\mathrm{AR}$ antagonist ARC 239, progesterone pretreatment did not modify the myometrial contracting effect of (-)-noradrenaline relative to the progesterone-treated control. The concentrationresponse curve was very flat, the difference between the 
a

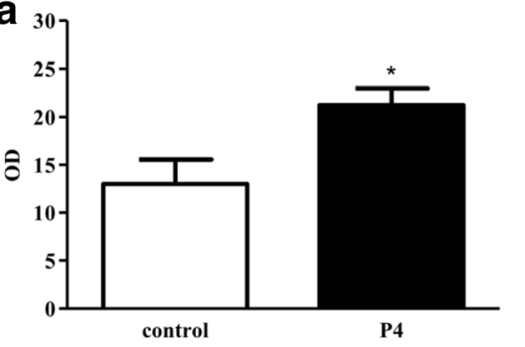

C $_{30}$

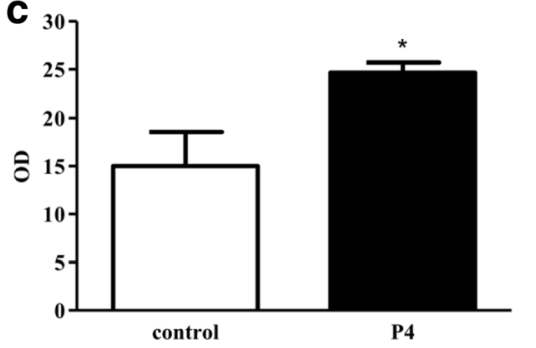

e

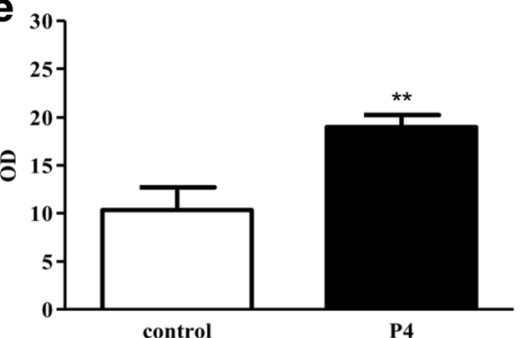

b

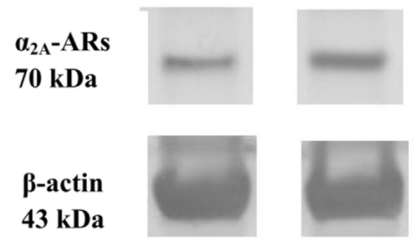

d

$\alpha_{2 \mathrm{~B}}$-ARs

$62 \mathrm{kDa}$
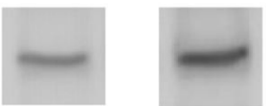

$\beta$-actin

$43 \mathrm{kDa}$
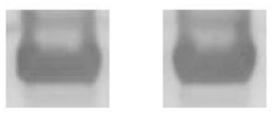

f

$\alpha_{2 \mathrm{C}}$-ARs
$60 \mathrm{kDa}$

$\beta$-actin
$43 \mathrm{kDa}$
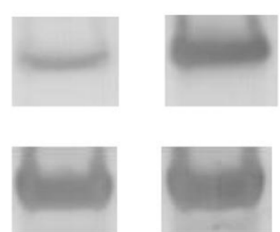

Fig. 2 Changes in the $a_{2}$-adrenergic receptor levels in the 22-day pregnant rat myometrium after progesterone pretreatment. The $a_{2}$-adrenergic receptor and $\beta$-actin Western blot products for $a_{2 A^{-}}(\mathbf{b}), a_{2 B^{-}}(\mathbf{d})$ and $a_{2 C^{-}}$adrenergic receptors (f). The 70, 62 and $60 \mathrm{kDa}$ proteins relate to the $a_{2 A R^{-}}, a_{2 B^{-}}$and $a_{2 C^{-}}$adrenergic receptors and $\beta$-actin, respectively. The antibody binding was expressed as optical density (OD) data (a) for $a_{2 A^{-}}$ (c) for $a_{2 B}$-and (e) for $a_{2 c}$-adrenergic receptors. The y axis shows the ratio of $a_{2}$-adrenergic receptors/ $\beta$-actin protein optical densities. The statistical analyses were carried out with the two-tailed unpaired t-test. ${ }^{*} p<0.05 ;{ }^{* *} p<0.01$

minimum and the maximum effect was less then $20 \%$ (Fig. 3b). ARC 239 reduced the (-)-noradrenaline-induced contractions, which were decreased further by progesterone pretreatment $(p<0.05)$ (Fig. 3a, b; Table 2c).

Progesterone pretreatment decreased the maximum contracting effect of $(-)$-noradrenaline in the presence of spiroxatrine as compared with the progesteronetreated control $(p<0.05)$ (Fig. 3b). Spiroxatrine enhanced the (-)-noradrenaline-induced contractions, which were enormously reduced by progesterone pretreatment $(p<0.001)$ (Fig. 3a, b; Table 2d).

In the presence of the combination of spiroxatrine + BRL 44408, progesterone pretreatment did not modify the maximum myometrial contracting effect of (-)-noradrenaline in comparison with the progesterone-treated control (Fig. 3b). The combination of the two compounds increased the (-)-noradrenaline-induced contractions, which were reduced by progesterone pretreatment $(p<0.001)$ (Fig. 3a, b; Table 2e).

\section{cAMP studies}

Progesterone pretreatment increased the myometrial cAMP level $(p<0.05)$ (Fig. 4) produced in the presence of (-)-noradrenaline. The myometrial cAMP level was also increased in the presence of BRL $44408(p<0.001)$, spiroxatrine $(p<0.001)$ and the spiroxatrine + BRL 44408 combination $(p<0.05)$. However, ARC 239 did not modify the amount of myometrial cAMP level after progesterone pretreatment. In addition, BRL 44408 $(p<0.05)$ and spiroxatrine $(p<0.01)$ increased the myometrial cAMP level compared to the progesterone-treated control.

\section{$\left[{ }^{35} \mathrm{~S}\right] \mathrm{GTP} \gamma \mathrm{S}$ binding assay studies}

In the presence of BRL 44408, (-)-noradrenaline increased the $\left[{ }^{35} \mathrm{~S}\right] \mathrm{GTP} Y \mathrm{~S}$ binding, which was slightly decreased after progesterone pretreatment $(p<0.01)$. In the presence of pertussis toxin, the $\left[{ }^{35} \mathrm{~S}\right] \mathrm{GTP} \gamma \mathrm{S}$ bindingstimulating effect of (-)-noradrenaline ceased, and it 


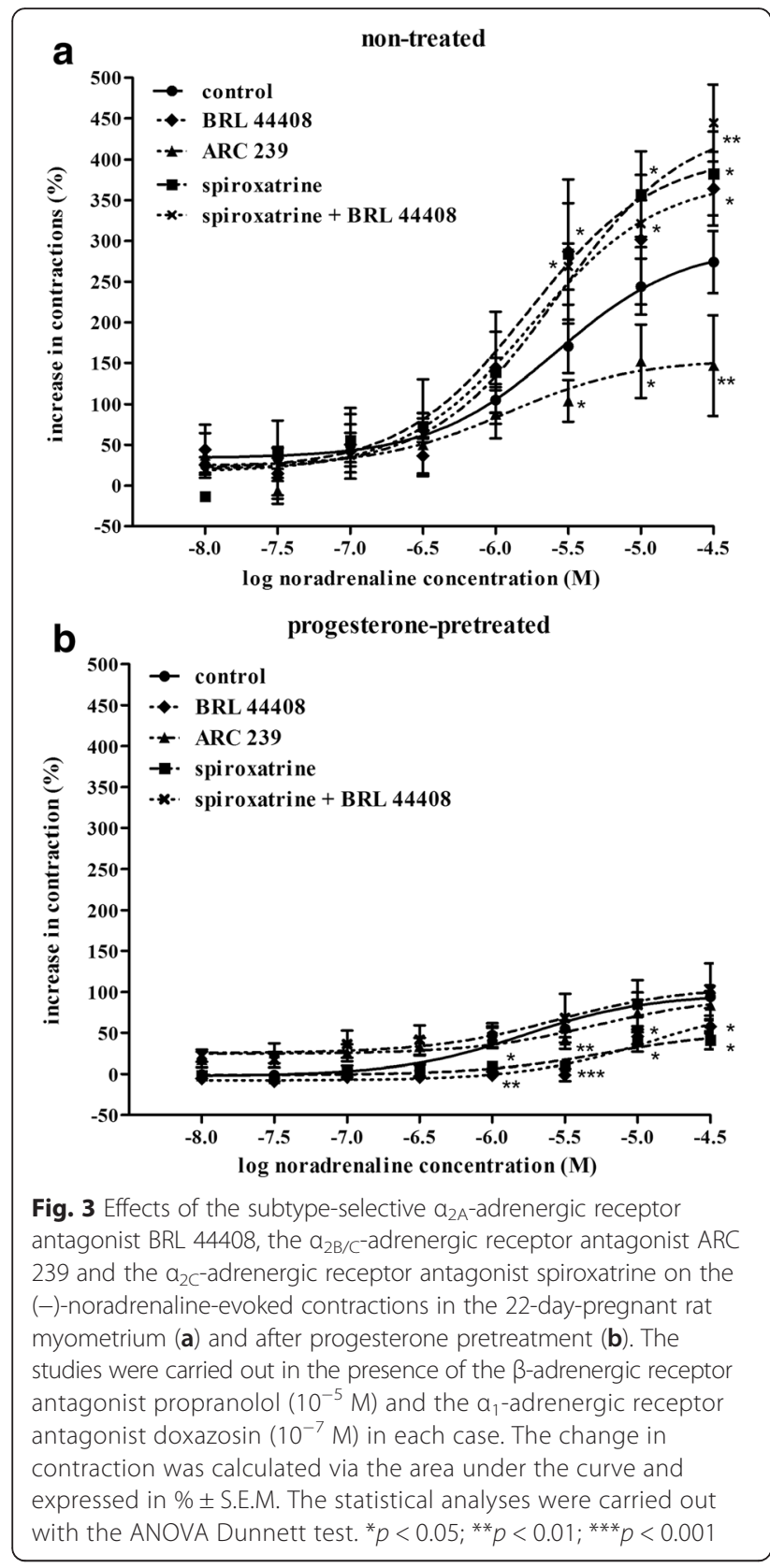

was decreased further after progesterone pretreatment $(p<0.01)$ (Fig. 5a).

In the presence of ARC 239, (-)-noradrenaline moderately increased the $\left[{ }^{35} \mathrm{~S}\right] \mathrm{GTP} \gamma \mathrm{S}$ binding and it was more elevated after progesterone pretreatment $(p<0.01)$. In the presence of pertussis toxin, the $\left[{ }^{35} \mathrm{~S}\right] \mathrm{GTP} \gamma \mathrm{S}$ bindingstimulating effect of (-)-noradrenaline ceased, which was not modified even by progesterone pretreatment (Fig. 5b).

In the presence of spiroxatrine, (-)-noradrenaline slightly increased the $\left[{ }^{35} \mathrm{~S}\right] \mathrm{GTP} \gamma \mathrm{S}$ binding and it was more elevated $(p<0.001)$ after progesterone pretreatment. In the presence of pertussis toxin, however,
Table 2 Changes in the uterus-contracting effect of $(-)$-noradrenaline ( $E_{50}$ and $E_{\max }$ values) in the absence of $a_{2}$-antagonists (a), or in the presence of an $a_{2 A}$-antagonist (b),

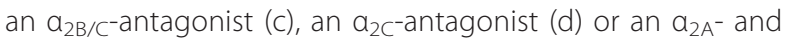
an $a_{2 c}$-antagonists (e) in the 22-day-pregnant rat without and after progesterone pretreatment

\begin{tabular}{lll}
\hline$C_{50}(M \pm S . E . M)$. & $E_{\max }(\% \pm S . E . M)$
\end{tabular}

(a) CONTROL

$\begin{array}{lll}\text { Non-treated } & 2.6 \times 10^{-6} \pm 1.2 \times 10^{-6} & 274.1 \pm 47.1 \\ \text { Progesterone-pretreated } & 1.7 \times 10^{-6} \pm 7.8 \times 10^{-7} \mathrm{~ns} & 94.0 \pm 14.4^{* *}\end{array}$

(b) BRL 44408

$\begin{array}{lll}\text { Non-treated } & 1.8 \times 10^{-6} \pm 6.4 \times 10^{-6} & 364.3 \pm 70.8 \\ \text { Progesterone-pretreated } & 1.2 \times 10^{-5} \pm 4.8 \times 10^{-6} \mathrm{~ns} & 57.4 \pm 12.9 * * *\end{array}$

(c) ARC 239

$\begin{array}{lll}\text { Non-treated } & 1.2 \times 10^{-6} \pm 1.1 \times 10^{-6} & 147.1 \pm 79.4 \\ \text { Progesterone-pretreated } & 5.3 \times 10^{-6} \pm 1.5 \times 10^{-6} \mathrm{~ns} & 83.7 \pm 22.1^{*}\end{array}$

(d) SPIROXATRINE

$\begin{array}{lll}\text { Non-treated } & 1.6 \times 10^{-6} \pm 5.4 \times 10^{-6} & 382.4 \pm 93.5 \\ \text { Progesterone-pretreated } & 5.9 \times 10^{-6} \pm 1.4 \times 10^{-6} \mathrm{~ns} & 41.0 \pm 15.2^{* * *}\end{array}$

(e) BRL $44408+$ SPIROXATRINE

$\begin{array}{lll}\text { Non-treated } & 2.9 \times 10^{-6} \pm 8.4 \times 10^{-7} & 444.6 \pm 51.3 \\ \text { Progesterone-pretreated } & 2.8 \times 10^{-6} \pm 2.7 \times 10^{-5} \text { ns } & 102.9 \pm 32.62{ }^{* * *}\end{array}$

$\mathrm{EC}_{50}$ : the concentration of (-)-noradrenaline alone or in the presence of an $a_{2}-A R$ antagonist which elicits half of the maximum contracting effect of $(-)$-noradrenaline. $E_{\text {max }}$ the maximum contracting effect of (-)-noradrenaline alone or in the presence of an $a_{2}-A R$ antagonist. Significance levels were calculated in comparison with non-treated values. ns: not significant: *: $p<0.05 ;{ }^{* *}: p<0.01 ; * * * 0<0.001$

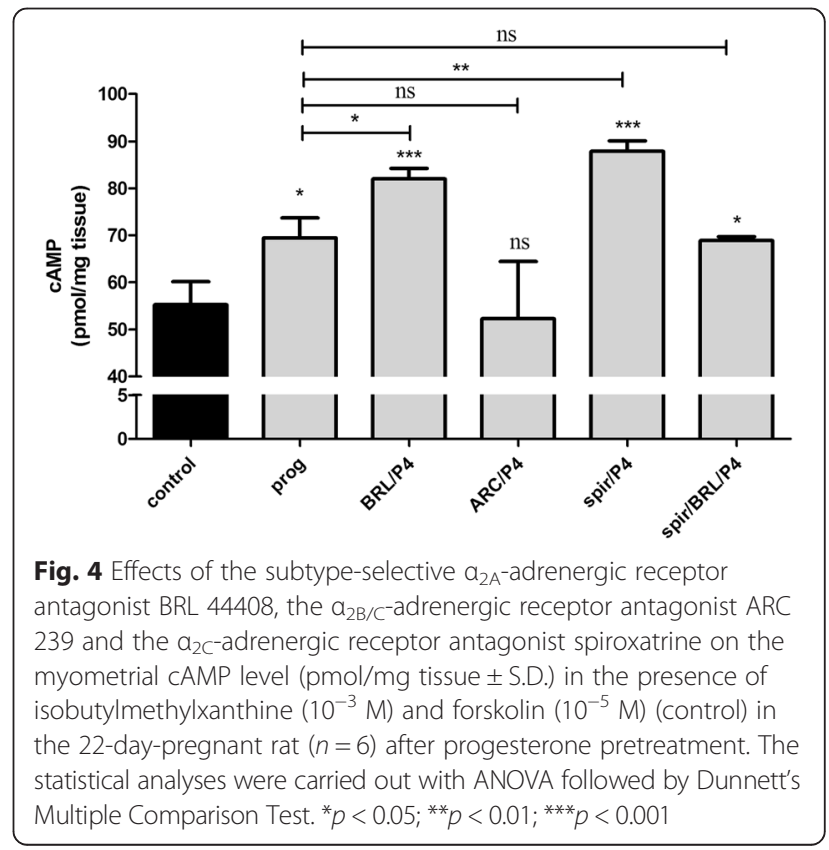




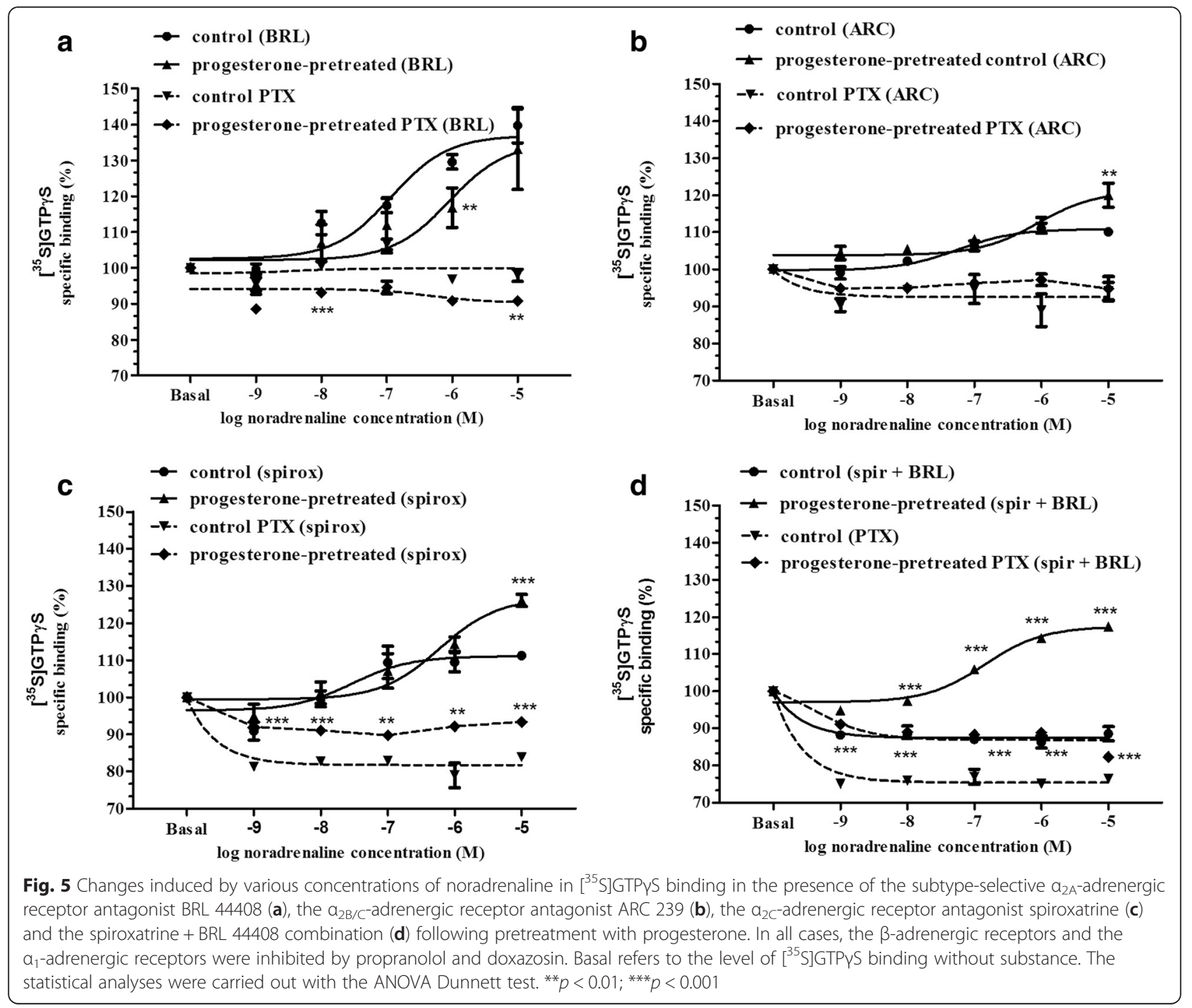

(-)-noradrenaline elicited a decline in the $\left[{ }^{35} \mathrm{~S}\right] \mathrm{GTP} \gamma \mathrm{S}$ binding, to below the basal level from a concentration of $1 \times 10^{-9} \mathrm{M}$. In the presence of pertussis toxin, progesterone pretreatment blocked the $\left[{ }^{35} \mathrm{~S}\right] \mathrm{GTP} \gamma \mathrm{S}$ binding-inhibitory effect of (-)-noradrenaline (Fig. 5c).

In the presence of the spiroxatrine + BRL 44408 combination, (-)-noradrenaline inhibited the $\left[{ }^{35} \mathrm{~S}\right] \mathrm{GTP} \gamma \mathrm{S}$ binding, but it was significantly increased after progesterone pretreatment $(p<0.001)$. In the presence of pertussis toxin, the spiroxatrine + BRL 44408 combination caused a dose-dependent inhibition in the $\left[{ }^{35} \mathrm{~S}\right] \mathrm{GTP} \gamma \mathrm{S}$ binding of (-)-noradrenaline, but the inhibition was reduced after progesterone pretreatment (Fig. $5 \mathrm{~d}$ ).

\section{Discussion}

Since progesterone and the adrenergic system play major roles in the myometrial function during gestation, the main focus of our study was to clarify the effects of progesterone on the $\alpha_{2}$-AR subtypes in the late-pregnant uterine function in vitro. The $\alpha_{2}$-AR-selective action of $(-)$-noradrenaline was provided by the application of the $\alpha_{1}$-blocker doxazosin and the $\beta$-AR blocker propanolol. The applications of subtype-selective antagonists gave us the possibility to investigate the subtype-specific $\alpha_{2}$-AR responses to (-)-noradrenaline and to detect the modification induced by progesterone pretreatment. In an earlier study, we determined the subtype-selective $\alpha_{2}$-AR action of (-)-noradrenaline, and our present work therefore focused mainly on the influence of progesterone as a modifier of the $\alpha_{2}$-AR response [27].

Progesterone pretreatment increased the mRNA and protein expression of the myometrial $\alpha_{2}$-AR subtypes, but decreased the (-)-noradrenaline-evoked myometrial contraction through the $\alpha_{2}$-ARs, which was similar to our earlier findings with the $\alpha_{1}$-ARs [17]. 
In the isolated organ bath studies, progesterone pretreatment ceased the (-)-noradrenaline-evoked myometrial contraction through the $\alpha_{2}$-ARs, although it practically ceased the myometrial contracting effect of the (-)-noradrenaline through the $\alpha_{2 \mathrm{~A}}$-ARs. Additionally, it abolished the myometrial contraction-increasing effect through the $\alpha_{2 B}$-ARs, and reversed the myometrial contracting effect in the presence of BRL 44408 and in the presence of spiroxatrine. Since there are no available $\alpha_{2 \mathrm{~A} / \mathrm{B}}-\mathrm{AR}$ blockers to produce only $\alpha_{2 \mathrm{C}}-\mathrm{AR}$ stimulation, we can only presume that progesterone maintained the myometrial relaxing effect through the increased number and function of $\alpha_{2 C}$-ARs.

To find an explanation of the weaker myometrial contractions via the $\alpha_{2 B}$-AR subtype after progesterone pretreatment, we measured the myometrial cAMP level, since the changes in the cAMP level are involved in the myometrial effect of the $\alpha_{2}$-ARs. Progesterone pretreatment increased the myometrial cAMP level, which additionally proves the decreased myometrial contracting effect of (-)-noradrenaline through the $\alpha_{2}$-ARs. It did not alter the cAMP level through the $\alpha_{2 \mathrm{~A}}$-ARs, which is in harmony with the result of the isolated organ bath studies that (-)-noradrenaline did not influence the myometrial contractions via these receptors after progesterone pretreatment. However, it increased the myometrial cAMP level through the $\alpha_{2 B}$-ARs, which can explain the weaker myometrium-contracting effect of (-)-noradrenaline in the presence of BRL 44408 (stimulation via $\alpha_{2 B^{-}}$and $\alpha_{2 C^{-}}$ARs), spiroxatrine (stimulation via $\alpha_{2 A^{-}}$and $\alpha_{2 B}-A R s$ ) and the spiroxatrine + BRL 44408 combination (stimulation via $\alpha_{2 B}-A R$ ).

The literature indicates that the $G_{i} / G_{s}$-activating property of $\alpha_{2}$-AR in rats changes during gestation, resulting in differences in the regulation of myometrial adenylyl cyclase activity at mid-pregnancy versus term [32]. Moreover, progesterone induces a change in the $G_{q} / G_{i}$ activating property of $\alpha_{1 \mathrm{AD}}-\mathrm{AR}$ in rats [17]. We therefore measured whether progesterone can modify the myometrial $\left[{ }^{35} \mathrm{~S}\right] \mathrm{GTP} \gamma \mathrm{S}$ binding of the $\alpha_{2}$-AR subtypes in the presence of the $G_{i}$ protein blocker pertussis toxin at the end of pregnancy. Progesterone did not modify the $\left[{ }^{35} \mathrm{~S}\right] \mathrm{GTP} \gamma \mathrm{S}$ binding of the $\alpha_{2 \mathrm{~A}}$-ARs. However, via the $\alpha_{2 A^{-}}$and $\alpha_{2 B^{-}}$ARs (with spiroxatrine), progesterone reversed the effect of (-)-noradrenaline on the $\left[{ }^{35} \mathrm{~S}\right] \mathrm{GTP} \gamma \mathrm{S}$ binding in the presence of pertussis toxin and also increased the $\left[{ }^{35} \mathrm{~S}\right] \mathrm{GTP} \gamma \mathrm{S}$ binding-stimulating effect of $(-)$-noradrenaline. These findings indicate that progesterone modifies the coupling of $\alpha_{2 B}$-ARs, but not the G protein binding of the $\alpha_{2 \mathrm{~A}}$-ARs. To confirm this hypothesis, we measured the myometrial $\left[{ }^{35} \mathrm{~S}\right] \mathrm{GTP} \gamma \mathrm{S}$ binding of the $\alpha_{2 B}$-AR subtype in the presence of the spiroxatrine $+B R L$ 44408 combination. Progesterone reversed the effect of (-)-noradrenaline on $\left[{ }^{35} \mathrm{~S}\right] \mathrm{GTP} \gamma \mathrm{S}$ binding in the presence of pertussis toxin and also reversed the $\left[{ }^{35} \mathrm{~S}\right] \mathrm{GTP} \gamma \mathrm{S}$ binding-stimulating effect of (-)-noradrenaline. This result suggests that, in the presence of predominance of progesterone, the $\alpha_{2 \mathrm{~B}}$-ARs are coupled, at least partially, to $G_{s}$ protein, which leads to the activation of adenylyl cyclase and decreases the (-)-noradrenaline-induced myometrial contraction via these receptors.

\section{Conclusions}

We conclude that progesterone increases the expression of each $\alpha_{2}$-AR subtype, and reduces the (-)-noradrenalineinduced myometrial contractions via the totality of these receptors. Progesterone blocks the G-protein coupling and cAMP production via the $\alpha_{2 \mathrm{~A}}$-ARs. In the case of the $\alpha_{2 C^{-}}$ ARs, we presume that progesterone treatment mainly induces the activation of the $\beta \gamma$ subunit of the $G_{i}$ protein, eliciting an increase in the smooth muscle cAMP level [19]. In the case of the $\alpha_{2 B}$-ARs, $G_{s}$ coupling is a determining factor in the function of the receptors after progesterone treatment, which leads to an increased cAMP level and decreased myometrial contraction.

Since the myometrial sensitivity to progesterone decreases at term, we assume that these changes can lead to the increased myometrial contraction near term via the $\alpha_{2}$-ARs. We presume that the effects of $\alpha_{2 C}$-AR agonists and $\alpha_{2 \mathrm{~B}}-\mathrm{AR}$ antagonists in combination with progesterone may open up new targets for drugs against premature birth.

\section{Abbreviations}

AR, Adrenergic receptor; CAMP, Cyclic adenosine monophosphate; $\mathrm{EC}_{50}$, Half of the maximum effect; $\mathrm{E}_{\text {max }}$, Maximum effect; $\mathrm{G}$ protein, Heterotrimeric guanine nucleotide binding regulatory protein; GTP $\gamma$, Guanosine-5'-O-( $\gamma$-thio)triphosphate; NA, Noradrenaline; PTX, Pertussis toxin; RT-PCR, Reverse transcriptase-polymerase chain reaction; s.c., Subcutaneous; Tris- $\mathrm{HCl}$, Tris(hidroxymethyl)aminomethane

\section{Funding}

The study was supported by a grant from the Hungarian National Research, Development and Innovation Office (NKFI), Budapest, Hungary; OTKA-108518.

\section{Availability of data and materials}

The information of all chemicals used in the study is available in the PubChem Substance Database.

\section{Authors' contributions}

All authors approved the final manuscript. JH-T: wrote the manuscript and participated in the experiments. JB: has participated in the experiments of contractility studies and CAMP determination. ED: has done the RT-PCR and Western blot studies. RS: has done the $\left[{ }^{35} \mathrm{~S}\right]-\mathrm{GTP} y S$ binding assay studies. AB: has participated in the design of $\left.{ }^{35} \mathrm{~S}\right]-\mathrm{GTP} Y \mathrm{~S}$ binding assay studies. SB: has participated and supervised the $\left[{ }^{35} \mathrm{~S}\right]$-GTPYS binding assay studies. RG: has supervised and organized the whole study Experiments and manuscript writing as corresponding author.

\section{Competing interests}

The authors declare that they have no competing interests.

Ethics approval and consent to participate

Ethical approval received from the Hungarian Ethics Committee for Animal Research (registration number: IV/198/2013). 


\section{Author details}

'Department of Pharmacodynamics and Biopharmacy, Faculty of Pharmacy, University of Szeged, Szeged H-6701, P.O. Box 121, Hungary. ${ }^{2}$ Institute of Biochemistry, Biological Research Centre, Hungarian Academy of Sciences, Temesvari krt 62, Szeged H-6726, Hungary.

Received: 20 April 2016 Accepted: 9 June 2016

Published online: 14 June 2016

\section{References}

1. Kamel RM. The onset of human parturition. Arch Gynecol Obstet. 2010. doi:10.1007/s00404-010-1365-9.

2. Blanks AM, Shmygol A, Thornton S. Preterm labour. Myometrial function in prematurity. Best Pract Res Clin Obstet Gynaecol. 2007. doi:10.1016/j. bpobgyn.2007.03.003.

3. Wray S. Insights from physiology into myometrial function and dysfunction. Exp Physiol. 2015. doi:10.1113/EP085131.

4. Illanes SE, Pérez-Sepúlveda A, Rice GE, Mitchell MD. Preterm labour: association between labour physiology, tocolysis and prevention. Expert Opin Investig Drugs. 2014. doi:10.1517/13543784.2014.905541.

5. Maggio L, Rouse DJ. Progesterone. Clin Obstet Gynecol. 2014 doi:10.1097/GRF.0000000000000039.

6. Norwitz ER, Bonney EA, Snegovskikh W, Williams MA, Phillippe M, Park JS, et al. Molecular Regulation of Parturition: The Role of the Decidual Clock. Cold Spri Harb Perspe Med. 2015. doi:10.1101/cshperspect.a023143.

7. Renthal NE, Williams KC, Montalbano AP, Chen CC, Gao L, Mendelson CR. Molecular Regulation of Parturition: A Myometrial Perspective. Cold Spring Harb Perspect Med. 2015;5(11). Medline: 26337112 doi: 10.1101/cshperspect. a023069.

8. Micks E, Raglan GB, Schulkin J. Bridging progestogens in pregnancy and pregnancy prevention. Endocr Connect. 2015. doi:10.1530/EC-15-0093.

9. Gáspár R, Hajagos-Tóth J. Calcium channel blockers as tocolytics: principles of their actions, adverse effects and therapeutic combinations. Pharm (Basel). 2013. doi:10.3390/ph6060689.

10. Marshall JM. Effects of ovarian steroids and pregnancy on adrenergic nerves of uterus and oviduct. Am J Physiol. 1981;240(5):C165-74

11. Hajagos-Tóth J, Bóta J, Ducza E, Csányi A, Tiszai Z, Borsodi A, Samavati R, Benyhe S, Gáspár R. The effects of estrogen on the a2-adrenergic receptor subtypes in ratuterine function in late pregnancy in vitro. CMJ. 2016;57(2): 100-9.

12. Roberts JM, Riemer RK, Bottari SP, Wu YY, Goldfien A. Hormonal regulation myometrial adrenergic responses: the receptor and beyond. J Dev Physiol. 1989;11(3):125-34

13. Dowell RT, Forsberg AL, Kauer CD. Decreased ovarian blood flow may confound the tocolytic effect of ritodrine. Gynecol Obstet Invest. 1994;37(3): $168-71$.

14. Engstrøm T, Vilhardt $H$, Bratholm P, Christensen NJ. Desensitization of beta2-adrenoceptor function in non-pregnant rat myometrium is modulated by sex steroids. J Endocrinol. 2001. doi:10.1677/joe.0.1700147.

15. Gáspár R, Ducza E, Mihályi A, Márki A, Kolarovszki-Sipiczki Z, Páldy E, et al. Pregnancy-induced decrease in the relaxant effect of terbutaline in the late-pregnant rat myometrium: role of G-protein activation and progesterone. Reprod. 2005. doi:10.1530/rep.1.00490.

16. Gálik M, Gáspár R, Kolarovszki-Sipiczki Z, Falkay G. Gestagen treatment enhances the tocolytic effect of salmeterol in hormone-induced preterm labor in the rat in vivo. Am J Obstet Gynecol. 2008. doi:10.1016/j.ajog.2007. 09.027.

17. Bóta J, Hajagos-Tóth J, Ducza E, Samavati R, Borsodi A, Benyhe S, et al. The effects of female sexual hormones on the expression and function of a1A- and a1D-adrenoceptor subtypes in the late-pregnant rat myometrium. Eur J Pharmacol. 2015. doi:10.1016/j.ejphar.2015.11.015.

18. Xie N, Liu L, Li Y, Yu C, Lam S, Shynlova O, et al. Expression and function of myometrial PSF suggest a role in progesterone withdrawal and the initiation of labor. Mol Endocrinol. 2012. doi:10.1210/me.2012-1088.

19. Zhou XB, Wang GX, Huneke B, Wieland T, Korth M. Pregnancy switches adrenergic signal transduction in rat and human uterine myocytes as probed by BKCa channel activity. J Physiol. 2000. doi:10.1111/j.1469-7793. 2000.t01-1-00339.x.

20. Knaus AE, Muthig V, Schickinger S, Moura E, Beetz N, Gilsbach R, et al. Alpha2-adrenoceptor subtypes-unexpected functions for receptors and ligands derived from gene-targeted mouse models. Neuroch Int. 2007. doi:10.1016/j.neuint.2007.06.036.

21. Civantos Calzada B, Aleixandre de Artiñano A. a-adrenoceptor subtypes Pharmacol Res. 2001. doi:10.1006/phrs.2001.0857.

22. Karim F, Roerig SC. Differential effects of antisense oligodeoxynucleotides directed against Gza and Goa on antinociception produced by spinal opioid and $\mathrm{a}_{2}$ adrenergic receptor agonists. Pain. 2000. doi:10.1016/ S0304-3959(00)00279-7.

23. Wang Q. a2-adrenergic receptors. Prim on the Auton Nerv Syst. 2012. doi:10.1016/B978-0-12-386525-0.00010-X.

24. Offermanns S. G-proteins as transducers in transmembrane signalling. Prog Biophys Mol Biol. 2003. doi:10.1016/S0079-6107(03)00052-X

25. Gyires K, Zádori ZS, Török T, Mátyus P. a -adrenoceptor subtypes-mediated physiological, pharmacological actions. Neurochem Int. 2009. doi:10.1016/j. neuint.2009.05.014.

26. Bouet-Alard R, Mhaouty-Kodja S, Limon-Boulez I, Coudouel N, Maltier JP, Legrand C. Heterogeneity of alpha 2-adrenoceptors in human and rat myometrium and differential expression during pregnancy. Br J Pharmacol. 1997. doi:10.1038/sj.bjp.0701555.

27. Gáspár R, Gál A, Gálik M, Ducza E, Minorics R, Kolarovszki-Sipiczki Z, et al. Different roles of alpha2-adrenoceptor subtypes in non-pregnant and late-pregnant uterine contractility in vitro in the rat. Neurochem Int. 2007. doi:10.1016/j.neuint.2007.06.029.

28. Hajagos-Tóth J, Falkay G, Gáspár R. Modification of the effect of nifedipine in the pregnant rat myometrium: the influence of progesterone and terbutaline. Life Sci. 2009. doi:10.1016/j.lfs.2009.08.008.

29. Chomczynski P, Sacchi N. Single-step method of RNA isolation by acid guanidinium thiocyanate-phenol-chloroform extraction. Anal Biochem. 1987. doi:10.1016/0003-2697(87)90021-2.

30. Hajagos-Tóth J, Hódi Á, Seres AB, Gáspár R. Effects of d- and I-limonene on the pregnant rat myometrium in vitro. Croat Med J. 2015. doi:10.3325/cmj. 2015.56.431.

31. Zádor F, Kocsis D, Borsodi A, Benyhe S. Micromolar concentrations of rimonabant directly inhibits delta opioid receptor specific ligand binding and agonist-induced G-protein activity. Neurochem Int. 2014. doi:10.1016/j. neuint.2013.12.005.

32. Mhaouty S, Cohen-Tannoudji J, Bouet-Alard R, Limon-Boulez I, Maltier JP, Legrand C. Characteristics of the alpha 2/beta 2-adrenergic receptor-coupled adenylyl cyclase system in rat myometrium during pregnancy. J Biol Chem. 1995. doi:10.1074/jbc.270.18.11012

\section{Submit your next manuscript to BioMed Central and we will help you at every step:}

- We accept pre-submission inquiries

- Our selector tool helps you to find the most relevant journal

- We provide round the clock customer support

- Convenient online submission

- Thorough peer review

- Inclusion in PubMed and all major indexing services

- Maximum visibility for your research

Submit your manuscript at www.biomedcentral.com/submit 